\section{SOI: $1.1 /$ TAS DOI: $10.15863 /$ TAS International Scientific Journal Theoretical \& Applied Science}

\author{
p-ISSN: 2308-4944 (print) e-ISSN: 2409-0085 (online) \\ Year: 2017 Issue: $05 \quad$ Volume: 49 \\ Published: $30.05 .2017 \quad \underline{\text { http://T-Science.org }}$
}

SECTION 13. Geography. History. Oceanology. Meteorology.
Gulchehra Sobirjonovna Rakhimova

Teacher,

Department of "Teaching the history of techniques", Kokand State Pedagogical Institute rakhimova.80@bk.ru

\author{
Adxam Azimov \\ Teacher \\ Kokand State Pedagogical Institute
}

Abduvaxid Mamadaliyev

Teacher

Kokand State Pedagogical Institute

\title{
FOREIGN LAWS TO PREVENT ENVIRONMENTAL PROBLEMS
}

Abstract: Currently, the national security of the Republic of Uzbekistan's domestic and foreign political life of the most important issues to be solved. Concern for the preservation of national security laws to protect the public and to avoid social and environmental problems will serve as an important criterion.

Key words: society, state, national security, the environment, criminal code, a person, fine, nature.

Language: English

Citation: Rakhimova GS, Azimov A, Mamadaliyev A (2017) FOREIGN LAWS TO PREVENT ENVIRONMENTAL PROBLEMS. ISJ Theoretical \& Applied Science, 05 (49): 177-179.

Soi: http://s-o-i.org/1.1/TAS-05-49-27 Doi: crossef https://dx.doi.org/10.15863/TAS.2017.05.49.27

\section{Introduction}

In recent years, endangering of human life from environmental factors is becoming the world problem. In preventing problems, in the first place is to receive laws and international legal documents in cooperation in all countries in order to protect national ecological environmental. The international standards of the world emphasized: "The nations of the world must work together to restore ecosystem and maintain the health. States are responsible for not materializing global environmental problems in their ecosystems and environments. The development of the state must be obliged to be provided on the basis of international rules, to provide with technology and financial resources to prevent environmental issues" [1]. Therefore, the legal system of criminal must be required to keep a high level of each state in accordance with the present day. The protection of human dignity in the field of criminal law of the countries of the world was systemized, on the basis of international laws. Sometimes, evidences on a great many of the negative effects of basic criminal liabilities to environmental pollution, global environment are given [2]. As M.D.Bergenevani said: "The issue is that duty for pollution of environment is paid by the oil companies during the transportation of the oil to the other countries. However, can the duty to prevent environmental damage justify itself financially? [3]

\section{Materials and Methods}

Not being superior of economic development from the environmental life for valuing in society, coming first of environmental fields from all spheres of the state, laws concerning with ecological purity among the population, rights on environmental issues did not give a clear assessment to the situation. Law on the criminal field of many countries only connected with humanity. Animals and environmental pollution were only reserved with environmental rights. Even if environment was disastrous damaged, it will be punished based on environmental legal norms. This means to cause that the damaging to environment of people in production is not significant factor and the ecological problems have originated among society. Using criminal penalties can achieve great results in environment protection. For example, Kazakhstan state according to Bergenevani: Environmental protection laws in Kazakhstan are more with agricultural production facilities and recorded of administrative penalties and fines by the state to enterprises which were treated improper to environmental norms. Reasons for causing to environmental problems were not taken severe punishment cases" [4].

Even if administrative penalties warn to the population, state authorities don't do in practice. It should be noted that the abandoned waste in different places isn't controlled and isn't undergone administrative liability.

As a result, damaging of the human ecology remain relating to emergence of new diseases recently. This shows the lack of attention to 


\begin{tabular}{|c|c|c|c|c|c|c|}
\hline Impact Factor: & $\begin{array}{l}\text { ISRA (India) } \\
\text { ISI (Dubai, UAE } \\
\text { GIF (Australia) } \\
\text { JIF }\end{array}$ & $\begin{array}{l}=1.344 \\
=0.829 \\
=0.564 \\
=1.500\end{array}$ & $\begin{array}{l}\text { SIS (USA) } \\
\text { PИНЦ (Russia) } \\
\text { ESJI (KZ) } \\
\text { SJIF (Morocco) }\end{array}$ & $\begin{array}{l}=0.912 \\
=0.234 \\
=\mathbf{3 . 8 6 0} \\
=\mathbf{2 . 0 3 1}\end{array}$ & $\begin{array}{l}\text { ICV (Poland) } \\
\text { PIF (India) } \\
\text { IBI (India) }\end{array}$ & $\begin{array}{l}=6.630 \\
=1.940 \\
=4.260\end{array}$ \\
\hline
\end{tabular}

environmental policy paid to environmental preservation.

Perhaps, criminal violation of environment does not affect to social sectors negatively, but statistics show the expansion of environmentally dangerous areas in countries. Some articles of RIO about "criminal prosecutions to some serious reasons which may danger to environment "were adopted. On the basis of this declaration, running consideration of laws and decisions on environment in every country intensify measures on preventing environmental problems little in country" [5].

The laws on the preservation of the environment of the former Soviet Union were not reflected in 1991.

As a result, the violation and issues of environment in a number of related republics are deteriorating. After the disintegration of the former Soviet republics, environmental policy of countries grew. Environmental policy in some economically developed republics began to resolve problems quickly and easily. Environmental policy was implemented with using tested methods in countries close to Europe countries. But ecological processes in Central Asia were implemented slowly with difficulties.

In February 1992, states in accordance with the rules of cooperation of the Commonwealth of Independent States signed agreement to cooperate with each other on "protection of human health and the environment" ecological tragedy and prevent them. The main objective of this agreement is protection of ecology and environmental ( preservation of the soil in cultivating, not breaking national legislation in using soil, forest, water, air, plants and animals, natural resources, economic zones, basins of water.

The Agreement vas controlled with the policy of ecology and environmental protection in 1992. the legitimate certificates of environmental protection were organized in the agreement and environmental norms and standards were taken into account. Interstate act also included in the fight against to chemical, and nuclear weapons, wastes of toxic and radioactive substances on the environmental, ecological security. In 1992, controlling agreement by the Interstate Environmental Alliance, the Environment Fund was agreed. DEI as a controller of the agreement makes measures and decisions on finding solutions in emergency [6]. Moreover, it helps countries that signed the agreement in emerged dangerous situations, makes concrete measures and represents the direct participation. Some articles on damage of other states to environmental were adopted in Criminal Code of the Russian Federation. Also, harsh punishments were given in China's criminal code for environmental damages. For example: "Jail punishment from 3 years till 10 years or high fine for damaging environment was indicated".

The protection of ecology and environment is being controlled according to the degrees of dangerousness for human life in developed countries of Europe.

In the criminal legislation of the republic of Bulgaria (Criminal code, $5^{\text {th }}$ section, $11^{\text {th }}$ chapter) criminal punishments are established for using atomic energy illegally. Followed by this code, several criminal cases were opened in the tragedy of Chernobel in 1986. The criminal code of the Poland: "A person who damages natural environment and its territory is fined: according to the amount of damage they are imprisoned for 2 years" [7]. More specifically, nature and its creatures, whether they are inanimate or animate, are protected by the law. It is concrete that damage to nature, in any case, naturally leads to changes in the ecology. For example: There is a significant difference between the attention given to their agricultural land and the land of the state in agricultural sector. However, they are related to each other with the land and the soil changes.

In article 266 of Chapter XXVI of the Criminal Code of the Kyrgyz Republic such given that environment, human health and life are harmed in the cases of not applying to arrangement during transportation of chemicals, bacteriological, radioactive waste, a high level of fines and imprisonment up to 2 years are used. In addition, if the death of human and animals are come as a result of pollution and large-scale poisoning of the environment, criminal proceedings will be risen and from 3 years to 5 years imprisonment will be sentenced.

Russian lawyer researcher O.L.Dubovinki said: "there is no any factual factors to environmental lesions caused to the death of the human, but there are some specific facts caused to diseases and it is certain that serious consequences can cause to the death of human" [8].

Such conditions can be seen in society that poisoning of water is being reason for the death of human. The laws on "Using water resources", "Environment preservation", “ Using nature resources in agriculture" were made in Australia, Great Britain and Belgium [9].

So, if we analyze the criminal codes of foreign states, law breaking in preservation of environment is carried out in the level of criminality.

\section{Conclusion}

To make equal Environmental protection with the criminal, impacts positively the civil on the prevention of offenses identified with environment; Specific environmental laws related to environmental protection must be developed in legislation institutes 


\begin{tabular}{l|lrl|l|ll} 
& ISRA (India) & $=\mathbf{1 . 3 4 4}$ & SIS (USA) & $=\mathbf{0 . 9 1 2}$ & ICV (Poland) & $=\mathbf{6 . 6 3 0}$ \\
Impact Factor: & ISI (Dubai, UAE) $=\mathbf{0 . 8 2 9}$ & PUHL (Russia) $=\mathbf{0 . 2 3 4}$ & PIF (India) & $=\mathbf{1 . 9 4 0}$ \\
& GIF (Australia) & $\mathbf{0 . 5 6 4}$ & ESJI (KZ) & $=3.860$ & IBI (India) & $=\mathbf{4 . 2 6 0}$
\end{tabular}

- Show more monitoring advertisements related to environmental legislation among population - To impose penalties for damage to the environment and to implement it in practice by state

If ecological rights in the international community make environmental damage among countries, large fines will lead to a political settlement. But in the inner regions of the state, penalties, fines to its citizens are not how much money. Citizens' attention to the environment is carried out by means of legislation will lead to the rebirth of a sense of responsibility.

Using execution of eco-fines in protection of environment and the application of taxes or fines that can fill environmental damages will serve as a material to improve the environment.

\section{References:}

1. (1999) RIO "Atrof-muxit va taraққijot хақіda" dekloracija 1992j 14 ijun'.// Наاқаro хиқиқ va xuzhzhatlar. M., Mysl'.

2. Kibal'nik A (2005) Universalizacija ugolovnopravovyh sistem i nacional'nyj interes// Ugolovnoe pravo. №5. p.31.

3. Bengeneva MD (2006) Jekologicheskaja bezopasnost' kak chast' nacional'noj bezopasnosti// Ugolovnoe pravo: strategija razvitija v XXI veke. Sbornik materialov tret'ej mezhdunarodnoj nauchno-prakticheskoj konferencii pod red. Ragora A.I. M. p.355.

4. Bergeneva DM (2017) Ukaz. Rabota. p. 356.

5. (2005) Mezhdunarodnoe jekologicheskoe pravo. Rostov-na-Donu. Feniks. p. 103.
6. Medvedev SN (2013) Ugolovnyj kodeks Kitajskij Narodnyj Respubliki 1997. Juridicheskie issledovanie. № 2. p. 58.

7. (2017) Ugolovnyj Kodeks Pol'shi. Glava XX. Prestuplenija protiv obshhej bezopasnosti. p. 187.

8. Dubovik OL (2005) Jekologicheskie prestuplenija. V kn.: Uchebnoprakticheskij Kommentarij k Ugolovnomu kodeksu Rossijskoj Federacii. Pod red. Zhalinskogo A.Je.M., "Jeksmo». p.774-775.

9. (2003) Doklad OON o sostojanii vodnyh resursov mira "Voda dlja ljudej, voda dlja zhizni". Programma ocenki vodnyh resursov mira 2003. 